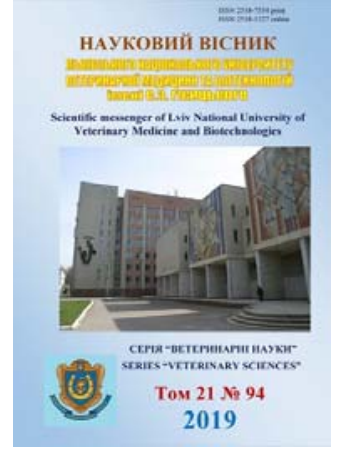

\section{Науковий вісник Иьвівського націонадьного університету ветеринарної медицини та біотехнологій імені С.З. Гжицького.}

\author{
Серія: Ветеринарні науки
}

\section{Scientific Messenger of Lviv National University of Veterinary Medicine and Biotechnologies. Series: Veterinary sciences}

ISSN 2518-7554 print ISSN 2518-1327 online doi: $10.32718 /$ nvlvet 9425

http://nvlvet.com.ua

\title{
Histostructure of the internal organs and skin of rats for the long-term effect of the drug "VetMikoDerm"
}

\author{
V.P. Martynyshyn
}

Stepan Gzhytskyi National University of Veterinary Medicine and Biotechnologies Lviv, Ukraine

Article info

Received 22.04.2019

Received in revised form 22.05.2019

Accepted 23.05.2019

Stepan Gzhytskyi National University of Veterinary Medicine and Biotechnologies Lviv, Pekarska Str., 50, Lviv, 79010, Ukraine. Tel.: +38-097-519-13-88 E-mail:doctorvetlviv@ukr.net

\begin{abstract}
Martynyshyn, V.P. (2019). Histostructure of the internal organs and skin of rats for the long-term effect of the drug "VetMikoDerm". Scientific Messenger of Lviv National University of Veterinary Medicine and Biotechnologies. Series: Veterinary sciences, 21(94), 136-141. doi: $10.32718 /$ nvlvet 9425
\end{abstract}

The investigation of the skin toxicity of the liniment "VetMikoDerm" for prolonged use was performed on young and healthy laboratory rats with intact skin, body weight 200-220 g. The investigated environment was applied to a clean, non-woolly area (dorsal/lateral surface) of at least $10 \%$ of the total surface area. The spotted thistle oil was applied to the pre-prepared area of the skin of the animals of the control group, and the other two experimental groups of animals got the studied drug at the doses of 50 (I) and $500 \mathrm{mg} / \mathrm{kg}$ (II), respectively. The drug was applied to the skin daily for 28 days. At the end of the experiment, after the decapitation of the rats conducted under the light etheric anesthesia, a complete pathoanatomical dissection was performed, the coefficients of the mass of the internal organs were determined, samples of liver, kidney and skin tissues were taken for their histological examination. According to the results it was established that the liver and kidneys histology, and skin of rats of the 1st experimental group were similar to those that were of the control animals. At the same time, receiving the maximum dose (10 times the therapeutic dose) of the drug "VetMikoDerm", the majority of rats of the 2 nd group showed a discomplication of the lamellar structure of the liver lobules, hepatocytes were placed in separate groups, sinusoidal capillaries were expanded. The presence of hepatocytes with heterogeneous, granular and weakly colored cytoplasm was observed in the central parts of the lobules, the nuclei of individual hepatocytes were increased, indicating the development of granular protein degeneration of the parenchyma. Histologically, under these conditions, foci of granular dystrophy of the epithelium of the vorticular and direct renal tubules with the expansion of their lumen were found in the structure of kidney of rats. The kernels of individual nephropyelitis had signs of karyopicnosis and cariorexis. The histological structure of skin of rats in all experimental groups was of the same type and consisted of the epidermis, dermis and hypodermis. Animals of the 2nd experimental group which repeatedly and for a long time were applied a "VetMikoDerm" lineulation in a dose that exceeded its optimal amount by 10 times showed the epidermal thickening, the presence of smallmesenchymal polymorphocytic infiltration, microcirculatory corneal disorder and sebaceous gland hyperplasia glands in the dermis that indicated the development of a compensatory-adaptive reaction in places of application of a 10-fold dose of the investigational medicinal product.

Key words: histostructures, liver, buds, skin.

\section{Гістоструктура внутрішніх органів та шкіри щурів за довготривалої дії препарату "ВетМікоДерм"}

\author{
В.П. Мартинишин
}

Львівський національний університет ветеринарної медицини та біотехнологій імені С.3. Гжиџького, м. Львів, Украӥна

Вивчення нашкірної токсичності лініменту “ВетМікоДерм” за тривалого застосування проводили на молодих і здорових лабораторних щурах з непошкодженою шкірою, масою тіла 200-220 г. Досліджуваний засіб наносили на чисту без шерсті ділянку (дорзально/бокова поверхня) площею не менще 10\% від загальної площі поверхні. Тваринам контрольної групи на попередньо підго- 
товлену ділянку шкіри наносили олію розторопмі плямистої, а двом дослідним групам тварин досліджуваний препарат у дозах 50 (I) i 500 мг/кг (II), відповідно. Препарат наносили на шкіру шзоденно впродовж 28 діб. По завершенні досліду після декапітації цурів, проведеної за легкого ефірного наркозу, проводили повний патологоанатомічний розтин, визначали коефіиієнти маси внутрішніх органів, відбирали зразки тканин печінки, нирок і шкіри для їхнього гістологічного дослідження. В результаті проведених досліджень встановлено, що гістоструктура печінки, нирок і шкіри щурів I дослідної групи була подібною до аналогічної у тварин контролю. Щодо тварин II групи, які отримували максимально досліджувану (десятиразову терапевтичну) дозу препарату “ВетМікоДерм”, то в більшості шурів виявляли дискомплексацію пластинчастої будови печінкових часточок, гепатоцити розміщувалися окремими групами, синусоїдні капіляри були розширеними. Переважно в центральних ділянках часточок спостерігали наявність гепатоцитів з неоднорідною, зернистою $і$ слабозабарвленою циитоплазмою, ядра окремих гепатоцитів збільшені, щцо вказувало на розвиток зернистої білкової дистрофії паренхіми. Гістологічно у структурі нирок щурів за цих умов виявляли вогнищза зернистої дистрофії епітелію звивистих і прямих ниркових канальців із розииренням їхнього просвіту. Ядра окремих нефроепітеліоцитів мали ознаки каріопікнозу і каріорексису. Гістологічна структура шкіри щурів усіх дослідних груп була однотипною $і$ складалася з епідермісу, дерми і гіподерми. У тварин ІІ дослідної групи, яким на ділянку шкіри багаторазово і впродовж тривалого часу наносили лінімент “ВетМікоДерм” у дозі, щзо в 10 разів перевищувала ї̈ оптимальну кількість, виявляли потовщення епідермісу, наявність дрібновогнищевих поліморфоклітинних інфільтратів, порушення мікрочиркуляторного русла та гіперплазію сальних залоз в дермі, щцо вказувало на розвиток компенсаторно-пристосувальної реакції в місиях нанесення 10-кратної дози досліджуваного лікарського засобу.

Ключові слова: гістоструктура, печінка, нирки, икіра.

\section{Ветуп}

Впровадження у лікувальну практику протигрибкових засобів з новими фармакологічними властивостями досягається оптимізацією лікування тварин на основі застосування відповідних фармакологічних форм. При цьому ефективність препарату залежатиме як від діючої субстанції, що входить до його складу, так і від формоутворюючої основи. За умов зовнішнього використання у практиці ветеринарної медицини найбільш широковживаними є мазі та лініменти (Pertsev et al., 1994). Перевагою останніх є “ніжна” дія без травмування грануляційної тканини, здатність створювати абсолютний контакт з рановою поверхнею, в тому числі й за наявності “кишень”, нориць чи змертвілих тканин. Цінними, на нашу думку, є лініменти, що виготовляються за типом розчинів на нелетких розчинниках, зокрема рослинних оліях (Zhungietu \& Granik, 2000; Hunchak et al., 2014). Ринок ветеринарних препаратів протимікробної і протигрибкової дії $є$ доволі широкий. Однак такі лікувальні засоби у формі мазей і лініментів не завжди стимулюють процеси регенерації тканин, а інші зазвичай мають незначні асептичні властивості. Тому пошук і розробка препаратів, що володіють доброю протимікробною і протигрибковою дією, оскільки часто причиною розвитку патологічних станів у тварин є поєднана контамінація мікроорганізмів і грибків, та проявляють, при цьому протизапальну і ранозагоювальну дію, $є$ надзвичайно актуальним питанням сучасної ветеринарної медицини. Не викликає жодних сумнівів перспектива пошуку нових біологічно активних сполук серед похідних 1,2,4-тріазолу. Ця гетероциклічна система володіє цілим рядом переваг: висока реакційна здатність, малотоксичність і висока біологічна активність (Parchenko et al., 2007; Parchenko, 2014). Нашу увагу привернула серія наукових праць вітчизняних та закордонних авторів, присвячених дослідженню протимікробних та протигрибкових властивостей похідних 1,2,4-тріазолу. При створенні нового препарату, з потенційно вираженими такими характеристиками, у формі лініменту під назвою "ВетМікоДерм" як діючої речовини використано тіопохідну 1,2,4-тріазолу (4-((5-(децилтіо)-4-метил-4Н-1, 2, 4тріазол-3-іл)метил)морфоліну), а за формоутворюючу основу - стандартизовану олію розторопші плямистої. Остання, за даними літератури (Leng-Perchlow, 1996; Sokol'skaja, 2002) та власних досліджень (Danko, 2011; Hunchak et al., 2014) є не лише доброю дисперсною системою для діючих речовин, а й самостійно (per se) проявляє виражені протизапальні, мембраностимулювальні та ранозагоювальні властивості (LengPerchlow, 1996; Sokol'skaja, 2002; Kaniuka et al., 2009).

Нашими попередніми дослідженнями детально вивчено параметри гострої і підгострої токсичності препарату "ВетМікоДерм" за його внутрішньошлункового введення лабораторним тваринам (білі миші, щурі) (Martynyshyn et al., 2017; Shcherbyna et al., 2018; Martynyshyn et al., 2018). Однак важливими є питання з'ясування впливу досліджуваного засобу за нашкірного примінення, оскільки запропонована лікарська форма препарату власне рекомендується для місцевого застосування.

Метою наших досліджень було встановлення гістологічної структури внутрішніх органів (печінка, нирки) та шкіри білих щурів при вивченні параметрів підгострої токсичності лініменту "ВетМікоДерм" за нашкірного застосування.

\section{Матеріали і методи досліджень}

Вивчення нашкірної токсичності Ветмікодерму за тривалого застосування проводили згідно з ОЕСД № 410 (Repeated Dose Dermal Toxicity: 21/28-day Study). Для досліду використовували молодих, здорових щурів з непошкодженою шкірою, масою тіла 200220 г. За день до нанесення досліджуваного засобу проводили видалення шерсті 3 дорзальної/бокової поверхні (щонайменше 10\% від загальної площі поверхні тіла). Повторне видалення шерсті проводили щотижня (Kotsiumbas et al., 2006).

За принципом аналогів було сформовано 3 групи тварин - по 6 щурів у кожній. Тваринам контрольної групи на попередньо підготовлену ділянку шкіри наносили розчин олії розторопші плямистої, I дослід- 
ної групи - 50 мг/кг і II дослідної групи - 500 мг/кг маси тіла.

Досліджуваний засіб наносили якомога рівніше на підготовлену дорсальну/бокову поверхню шкіри. Лінімент “ВетМікоДерм” наносили на шкіру щоденно упродовж 28 діб. Досліджуваний засіб тримали в контакті зі шкірою за допомогою пористої марлевої пов'язки та неподразливої стрічки, щоденно впродовж 6 годин. Після закінчення періоду експозиції досліджуваний засіб видаляли, де це можливо, використовуючи при цьому воду або відповідний розчинник.

На наступну добу після закінчення останнього нанесення, лабораторних тварин, за легкого ефірного наркозу, декапітували, відбирали проби крові. Проводили повний патологоанатомічний розтин, визначали коефіцієнти маси внутрішніх органів, відбирали матеріал для гістологічного дослідження (Horalskyi et al., 2005).

Досліджуваний матеріал (шматочки печінки, нирок та шкіри) фіксували у $10 \%$ розчині нейтрального формаліну 3 подальшою проводкою через етиловий спирт зростаючої концентрації та заливкою у парафін. Гістозрізи виготовляли на санному мікротомі товщиною 5-7 мкм. Фарбування гістозрізів проводили гематоксиліном та еозином згідно із загальноприйнятими гістологічними методиками (Merkulov, 1969; Pototskyi, 2001; Vlizlo, 2012). Мікроскопію проводили за допомогою мікроскопа OLIMPUS CX-41 та фотокамери OLIMPUS C - 5050.

\section{Результати та їх обговорення}

При патологоанатомічному розтині щурів контрольної та дослідних груп розміщення внутрішніх органів грудної та черевної порожнин було анатомічно правильним. При цьому очеревина гладка, блискуча, волога, без нашарувань. Вміст черевної порожнини незначний, прозорий, водянистої консистенції. У грудній порожнині вмістимого не відзначено.

Серце мало конусовидну форму, перикард прозорий без нашарувань, міокард - пр ужної консистенції

червоного кольору. Легені були блідо-рожевого кольору, пухкої консистенції, розділені на частки, легенева та костальна плевра гладенькі, блискучі без нашарувань. Шлунок і тонкі кишки були заповнені кормовими масами, товстий кишечник - сформованими каловими масами, слизова оболонка блідо-рожева, блискуча, волога, без нашарувань. Печінка темночервоного кольору, капсула гладка, краї гострі, із характерною структурою на розрізі, пружної консистенції, у щурів, які отримували 10-кратну терапевтичну дозу препарату “ВетМікоДерм”, спостерігали наявність поодиноких вогнищ світло-коричневого кольору із згладженим рисунком паренхіми на розрізі. Нирки бобовидної форми, темно-червоного кольору, краї розрізу сходились, межа між кірковою і мозковою зонами була збережена, капсула знімалася легко. Селезінка темно-вишневого кольору, краї гострі, на розрізі структура збережена, зіскребок помірний. Лімфатичні вузли брижі - без макроскопічних змін. Підшлункова залоза часточкової будови, пружної консистенції, світло-рожевого кольору.

При гістологічному дослідженні структура печінки усіх досліджуваних груп щурів збережена і представлена часточковою будовою 3 радіальним розміщенням печінкових балок навколо центральної вени, зона тріад без структурних особливостей, судини органу спустошені або помірно наповнені. Гепатоцити полігональної форми, цитоплазма однорідна, добре забарвлена, ядра округлої форми, чітко контуровані.

У більшості щурів, які отримували 10-кратну терапевтичну дозу препарату “ВетМікоДерм”, найчастіше виявляли дискомплексацію пластинчатої будови печінкових часточок, гепатоцити розміщувалися окремими групами, синусоїдні капіляри розширені, місцями периваскулярні поліморфоклітинні інфільтрати. Переважно в центральних ділянках часточок спостерігали наявність гепатоцитів 3 неоднорідною, зернистою, слабо забарвленою цитоплазмою, ядра окремих гепатоцитів збільшені, що вказувало на розвиток зернистої білкової дистрофії паренхіми (рис. 13).

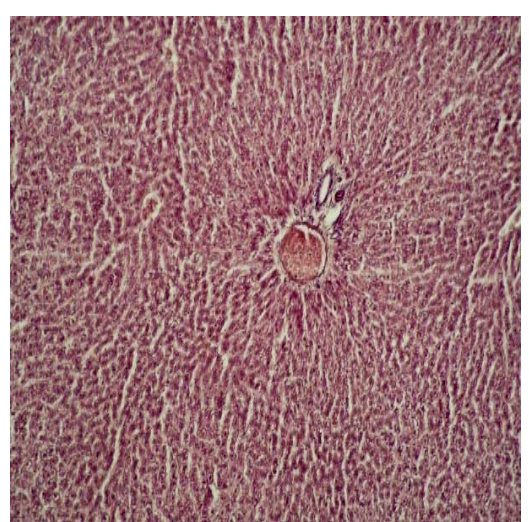

Рис. 1. Печінка. Розширення та переповнення кров'ю венозних судин, у щура II дослідної групи. Гематоксилін та еозин. Ок. 10 , об. 10

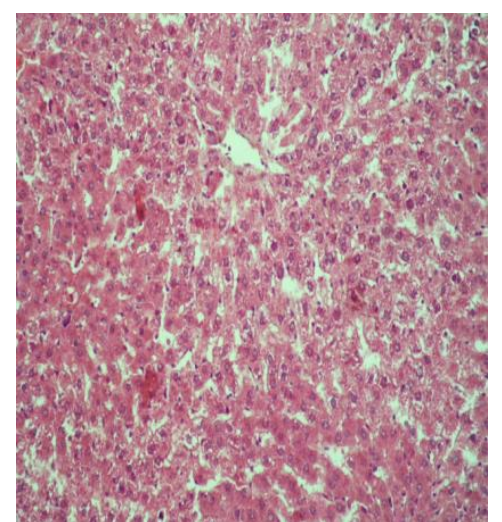

Рис. 2. Печінка щура II дослідної групи. Дискомплексація пластинчатої будови часточки. Гематоксилін та еозин. Ок. 10, об. 20

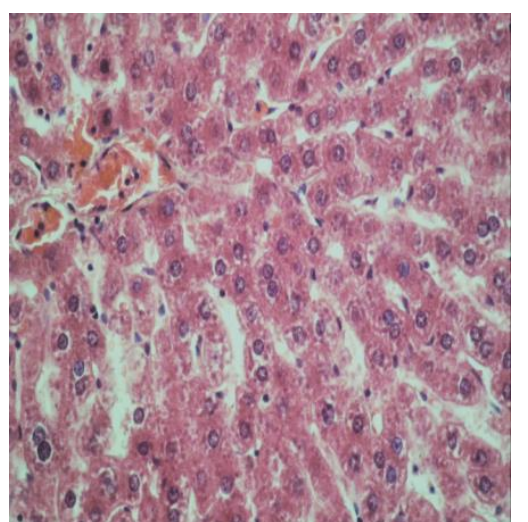

Рис. 3. Печінка щура II дослідної групи. Цитоплазма гепатоцитів зерниста, неоднорідно зафарбована, окремі ядра гіпертрофовані. Синусоїдні капіляри розширені. Гематоксилін та еозин. Ок. 10, об. 40 
Гістологічно в структурі нирок щурів, яким застосовували 10-кратну терапевтичну дозу препарату "ВетМікоДерм" впродовж 28 діб, виявляли вогнища зернистої дистрофії епітелію звивистих і прямих ниркових канальців 3 розширенням їхнього просвіту. Ядра окремих нефроепітеліоцитів з ознаками каріопі-

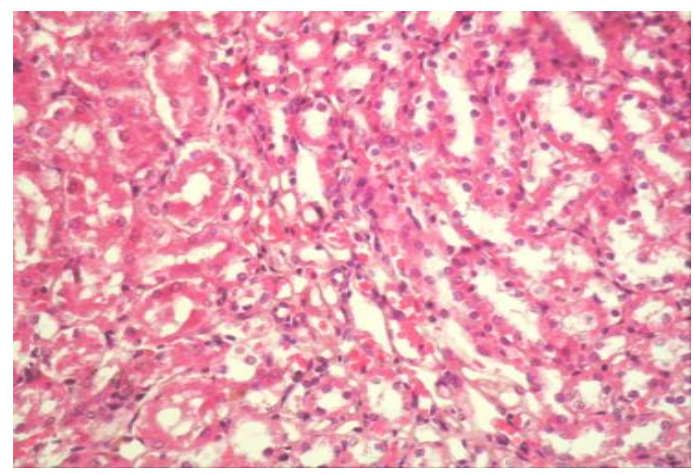

Рис. 4. Нирка щура II-ї дослідної групи. Зерниста дистрофія епітелію ниркових канальців.

Гематоксилін та еозин. Ок. 10, об. 20

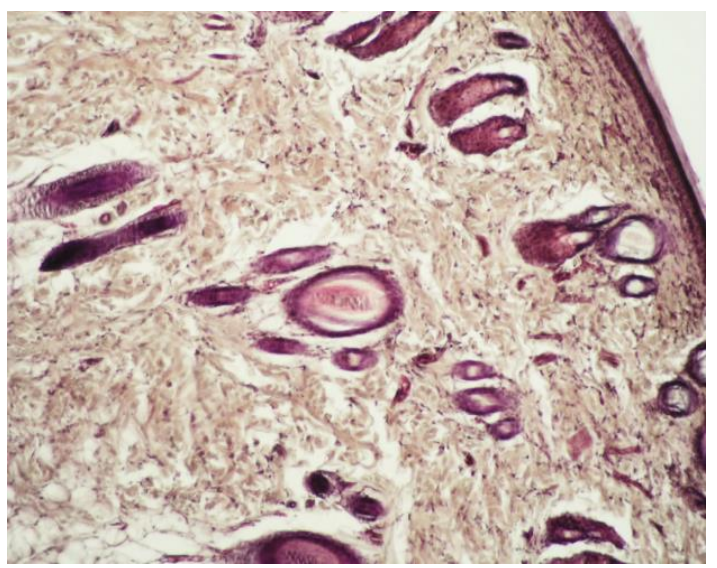

Рис. 6. Шкіра щура II дослідної групи: а - епідерміс; б -дерма; в - гіподерміс. Гематоксилін та еозин. Ок. 10, об. 10

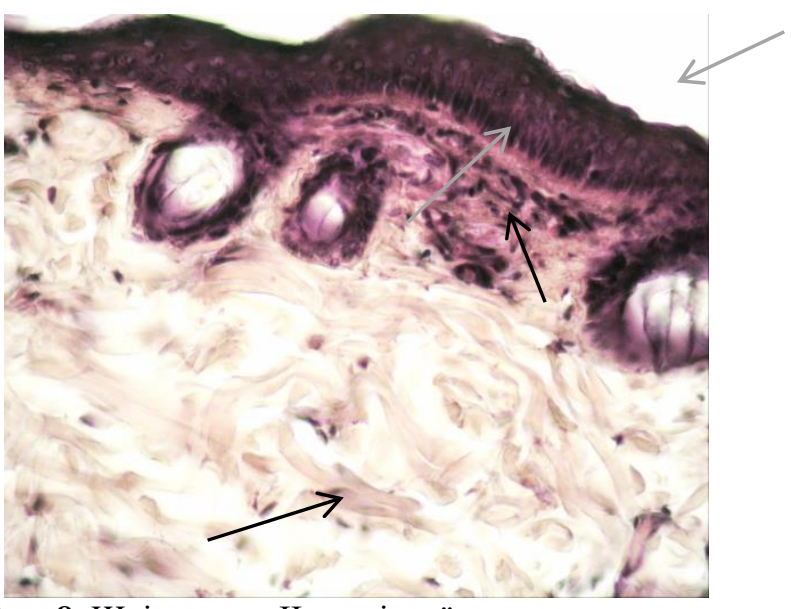

Рис. 8. Шкіра щура II дослідної групи: а - вогнищева клітинна інфільтрація в дермі; б - епідерміс;

в - цилін дричні клітини базального шару; г- колагенові волокна. Гематоксилін та еозин. Ок. 10, об. 40 кнозу, каріорексису. Капілярна сітка деяких ниркових клубочків ущільнена, капсула ШумлянськогоБоумена розтягнута, без вмістимого (рис. 4-5).

Гістологічна структура шкіри щурів усіх досліджуваних груп була однотипною і складалася з епідермісу, дерми та гіподерми (рис. 6-7).

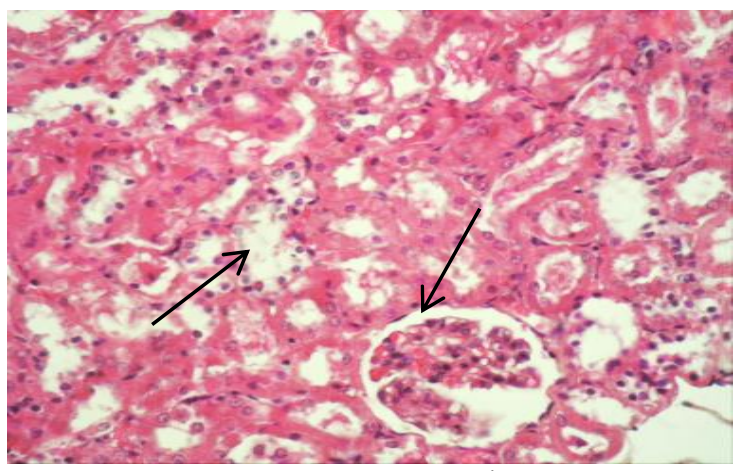

Рис. 5. Нирка щура II-ї дослідної групи. Дистрофічно-некротичні зміни звивистих канальців, ущільнення ниркових клубочків.

Гематоксилін та еозин. Ок. 10, об. 40

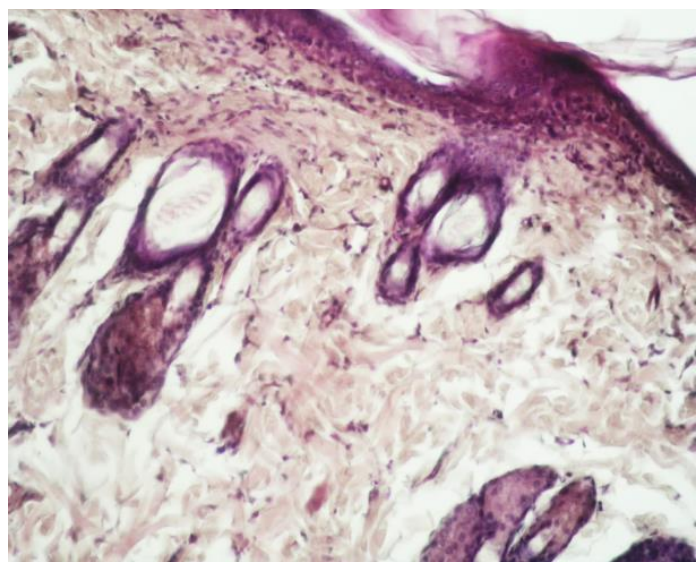

Рис. 7. Шкіра щура II - дослідної групи. а - епідерміс; б - дерма; в - волосяні фолікули; г - сальні залози. Гематоксилін та еозин. Ок. 10, об. 20.

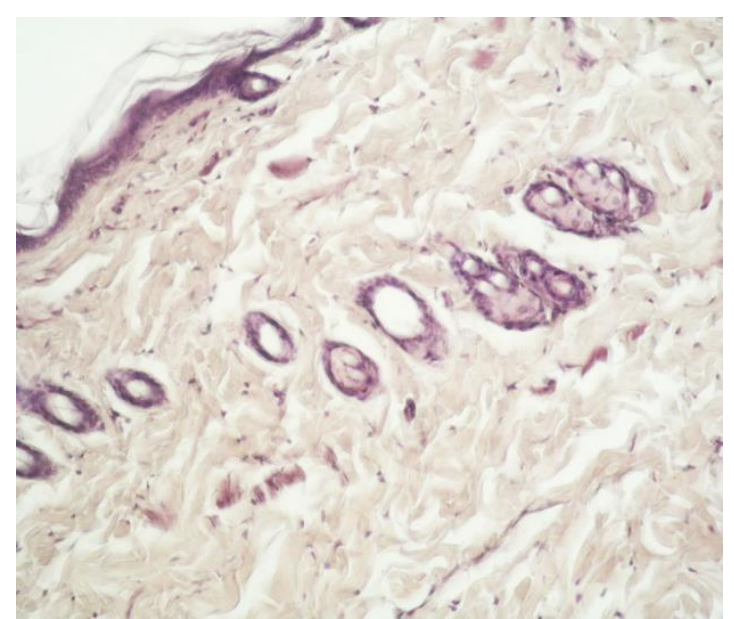

Рис. 9. Шкіра щура I- дослідної групи: а - епідерміс; б - волосяні фолікули; в - сальні залози; г - колагенові волокна. Гематоксилін та еозин. Ок. 10 , об. 10 
Епідерміс у щурів представлений багатошаровим плоским зроговілим епітелієм. Базальний шар збережений і складався з циліндричних клітин. Також добре проглядався шипуватий, зернистий та роговий шари.

Дерма, або власне шкіра, складалася із пучків еластичних, колагенових волокон та клітинних елементів: гістіоцитів, фібробластів. У шкірі щурів II групи, яким наносили досліджуваний лінімент у 10-кратній терапевтичній дозі, відмічали потовщення епідермісу

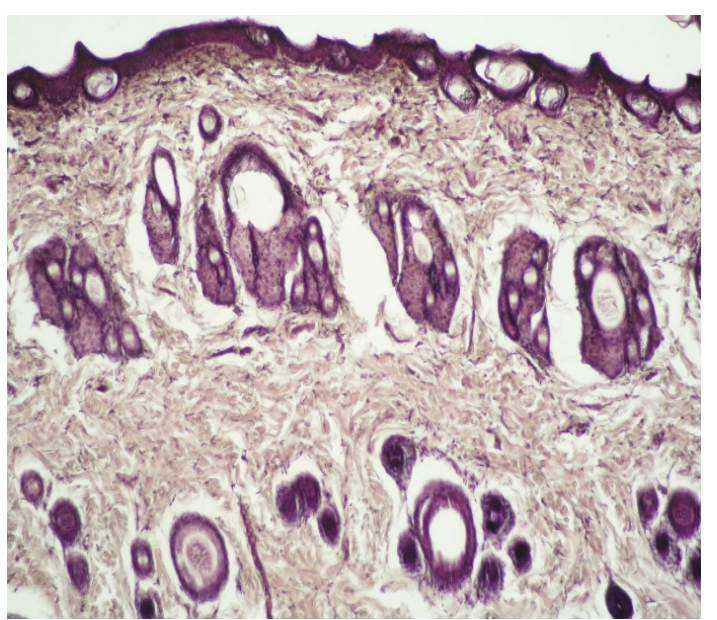

Рис. 10. Шкіра щура II дослідної групи: а - епідерміс; б - волосяні фолікули; в - гіперплазія сальних залоз. Гематоксилін та еозин. Ок. 10, об. 10

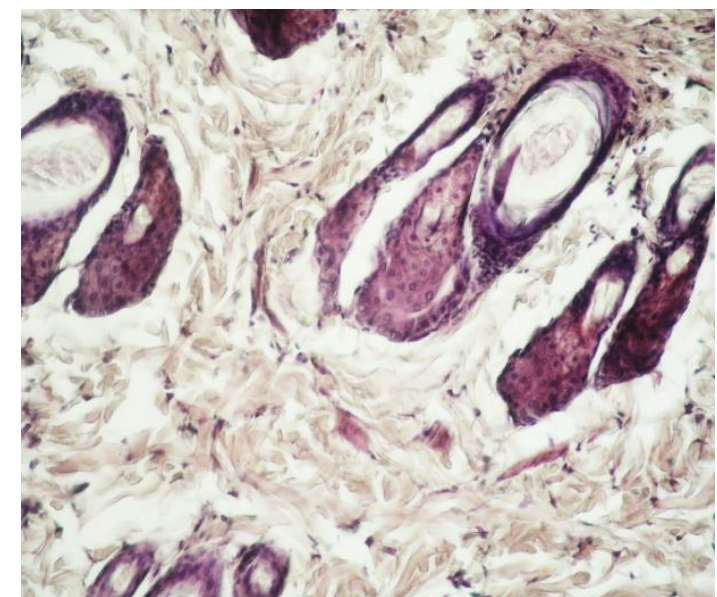

Рис. 12. Шкіра щура II дослідної групи: а - волосяні фолікули; б - сальні залози; в - колагенові волокна. Гематоксилін та еозин. Ок. 10, об. 20

\section{Висновки}

За нашкірного застосування лініменту "ВетМікоДерм” при вивченні підгострої токсичності макроскопічна та мікроскопічна структура досліджуваних внутрішніх органів та шкіри щурів збережена. У більшості щурів, яким наносили 10-кратну терапевтичну дозу лініменту, а саме 500 мг/кг маси тіла впродовж 28 діб, гістологічно встановлено вогнищеву білкову дистрофію в печінці і нирках зворотного характеру, у шкірі - потовщення епідермісу, за рахунок проліферації клітин шипуватого та зернистого шарів із деяким порушенням диференціації клітин базального шару, збільшенням кількості клітин 3 перинуклеарною вакулолізацією та підвищення мітотичної активності клітин, а також потовщення та розшарування самої базальної мембрани (рис. 8-9).

В дермі виявляли поліморфоклітинні інфільтрати, порушення мікроциркуляторного русла, розростання (гіперплазія) сальних залоз з активною проліферацією та диференціацією клітин (10-13).

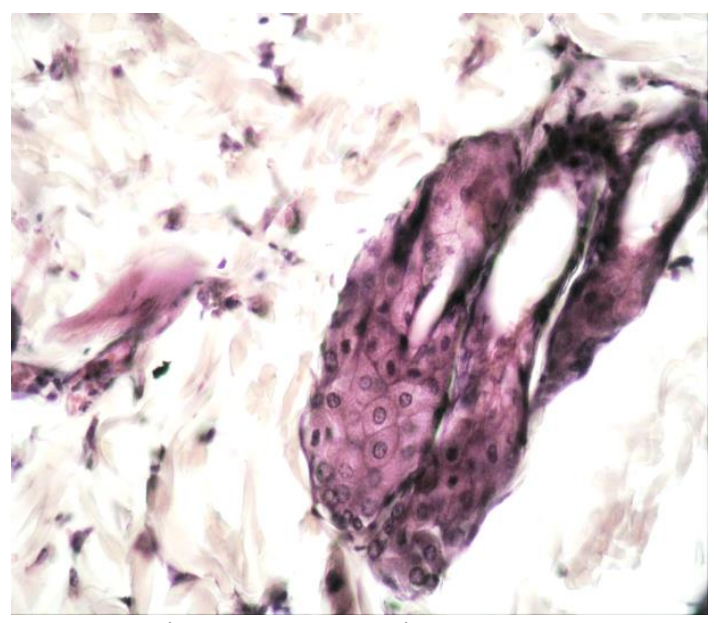

Рис. 11. Шкіра щура II дослідної групи. Малодиферен ційовані клітини кінцевого відділу сальної залози. Гематоксилін та еозин. Ок. 10, об. 40

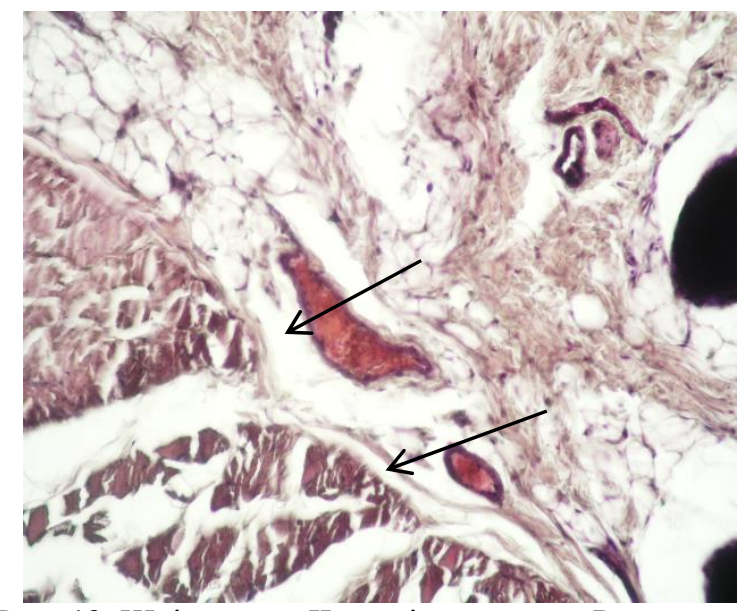

Рис. 13. Шкіра щура II дослідної групи. Розширення та переповнення кров'ю судин мікроциркуляторного русла. Гематоксилін та еозин. Ок. 10, об. 10

наявність дрібновогнищевих поліморфоклітинних інфільтратів, порушення мікроциркуляторного русла та гіперплазію сальних залоз в дермі, що вказувало на розвиток компенсаторно-пристосувальної реакції в місцях нанесення 10-кратної дози досліджуваного лікарського засобу.

\section{References}

Danko, H.V. (2011). Membranostabilizuvalni vlastyvosti mazi, yaka mistyt oliiu plodiv roztoropshi pliamystoi. 
Naukovo-tekhnichnyi biuleten instytutu biolohii tvaryn, DNDKI vetpreparativ ta kor-movykh dobavok, 12(3-4), 176-180 (in Ukrainian).

Horalskyi, L.P., Khomych, V.T., \& Kononskyi, O.I. (2005). Osnovy histolohichnoi tekhniky i morfofunktsionalni metody doslidzhen u normi ta pry patolohii. Navchalnyi posibnyk. Zhytomyr: Polissia (in Ukrainian).

Hunchak, V.M., Danko, H.V., Slobodiuk, N.M., \& Hutyi, B.V. (2014), Patent na korysnu model № 94227 Ukrainy, MPK (2014.01). A61K31/47. Liniment dlia likuvannia tvaryn z hniino-nekrotychnymy urazhenniamy shkiry; zaiavnyky ta patentovlasnyky Lvivskyi natsionalnyi universytet veterynarnoi medytsyny ta biote-khnolohii imeni S.Z. Hzhytskoho. Zaiavl. 31.03.2014; Opubl. 10.11.2014, Biul. № 21 . http:/uapatents.com/5-94227-liniment-dlyalikuvannya-tvarin-z-gnijjno-nekrotichnimiurazhennyami-shkiri.html (in Ukrainian).

Kaniuka, O.I., Hunchak, V.M., \& Danko, H.V. (2009). Farmakokinetyka i biotransformatsiia flavolihnativ roztorop-shi pliamystoi. Naukovyi visnyk LNUVM i BT imeni S.Z. Hzhytskoho, 11, 2(41), 124-127 (in Ukrainian).

Kotsiumbas, I.Ia., Malyk, O.E., \& Patereha, I.P. (2006). Doklinichni doslidzhennia veterynarnykh likarskykh zasobiv. Lviv: Triada plius (in Ukrainian).

Leng-Perchlow, E. (1996). Properties and medical use of flavolignans (silymarin) from silybum mariarum. Phytother. Res., 10, 25-26.

Martynyshyn, V., Hunchak, V., Parchenko, V., Gutyi, B., Shcherbyna, R. (2018). Evalution of a new antifuncal drug cumulative powers based on 1,2,4-triazole derivatives. Miedzynarodowa konferencia naukowa "Lwowsko-Wroclawska szkola weterynaryyna", Lwow-Wroclaw, 113-118.

Martynyshyn, V.P., Hunchak, V.M., Hutyi, B.V., Hlukh, O.S. (2017). Do metodyky pryhotuvannia linimentu na osnovi tiopokhidnoi triazolu ta yoho otsinka za fizychnymy vlastyvostiamy i diieiu na okremi mikroorhanizmy ta hrybky. Naukovyi visnyk LNUVMB imeni S.Z. Hzhytskoho, 19(82), 36-40. doi: 10.15421/nvlvet8208 (in Ukrainian).
Merkulov, G.A. (1969). Kurs patologogistologicheskoj tehniki. L.: Medicina (in Russian).

Panasenko, O.I. (2005). Syntez, peretvorennia, fizykokhimichni ta biolohichni vlastyvosti pokhidnykh 1,2,4-triazolu; dys.. d-ra farm. nauk. K. (in Ukrainian).

Parchenko, V.V. (2014). Syntez, peretvorennia, fizykokhimichni ta biolohichni vlastyvosti v riadu 5-furylzamishchenykh 1,2,4-triazol-3-tioniv; dys. doktor farmatsevtychnykh nauk. Zaporizhzhia (in Ukrainian).

Parchenko, V.V., Panasenko, O.I., \& Knysh, Ye.H. (2007). Fizyko-khimichni vlastyvosti ta hostra toksychnist pokhidnykh 3-atsylalkiltio-1,2,4-triazoliv. Farmatsevtychnyi chasopys, 2(2), 41-43. doi: 10.11603/2312-0967.2007.2.3153 (in Ukrainian).

Pertsev, I.M. Datsenko, B.M., \& Hunko, V.H. (1994). Konstruiuvannia likarskykh system bahato spriamovanoi dii u vyhliadi mazei dlia likuvannia infikovanykh ran. Visnyk farmatsii, 1-2, 91-95 (in Ukrainian).

Pototskyi, M.K. (2001). Osnovy histopatolohichnoi tekhniky. Metodychni vkazivky. Kyiv (in Ukrainian).

Pruhlo, Ye.S., Shcherbyna, R.O., Panasenko, T.V., \& Knysh, Ye.H. (2015). Doslidzhennia hostroi toksychnosti 3-R-4-R1-1,2,4-triazol-5-tioliv v eksperymentakh na shchurakh. Ukrainskyi farmatsevtychnyi zhurnal, 2(37), 34-37. http://nbuv.gov.ua/UJRN/ ubfj 201528 (in Ukrainian).

Shcherbyna, R., Parshenko, V., Martynyshyn, V., \& Hunchak, V. (2018). Evaluation of acute and subacute toxicity of oil liniment based on 4-((5-(decyltio)-4methyl-4H-1,2,4-triazol-3-yl)morpholine). Ankara Ecz. Fak. Derg. Y. Fac. Pharm. Ankara, 42(X), 4348. doi: 10.1501/Eczfak-0000000601.

Sokol'skaja, T.A. (2002). Sozdanie lekarstvennyh sredstv iz plodov rastoropshi pjatnistoj (poluchenie, standartizacija i kontrol' kachestva). Farmacija, 1, 32 (in Russian).

Vlizlo, V.V. (2012). Laboratorni metody doslidzhen u biolohii, tvarynnytstvi ta veterynarnii medytsyni. Lviv, Dovidnyk (in Ukrainian).

Zhungietu, G.I., \& Granik, V.G. (2000). Osnovnye principy konstruirovanie lekarstv. Kishinev (in Russian). 